\title{
Laparoscopic ovum pick up (LOPU) in goats: from hormonal treatment to oocyte possible destinations*
}

\author{
Colheita de oócitos por laparoscopia em caprinos: \\ do tratamento hormonal aos possíveis destinos dos oócitos
}

Joanna Maria Gonçalves de Souza-Fabjan, ${ }^{* *, * * *}$ Yann Locatelli, ${ }^{* * * * * *}$ Vicente José de Figueiredo Freitas, ${ }^{* * *}$ Pascal Mermillod ${ }^{* *}$

\begin{abstract}
Whether we are collecting oocytes from donors as part of a program of in vitro embryo production (IVP) and/or to promote advances in emerging biotechnologies as cloning and transgenesis, the success rate depends on the development of methodological aspects of recovering oocytes. To succeed, sufficient number of good quality oocytes is the prerequisite for various reproductive techniques and laparoscopic ovum pick up (LOPU) is the recommended technique for obtaining them from live goats. However, the variability of the quantity and quality of the oocytes collected still limits the large-scale use of this technology. Under the current conditions, too large variability is reported with oocyte recovery rates ranging from 40 to $90 \%$, and the number of harvested oocytes per female between 4 and 14, in different laboratories. This variability can depend on either intrinsic characteristic of the donors, such as breed, age, individual response or on aspects that we might be able to control, such as stimulation treatment, type of needle, aspiration pressure, among others. We believe that new investigations should contribute to significant improvement of LOPU yield. This review aims to report different factors influencing goat donor response for LOPU, presenting main steps for oocytes recovery as well as technical alternatives for improving LOPU efficiency. Furthermore, it is aimed to discuss about the potential use of goat oocytes after their recovery by LOPU and present overall results in goat IVP worldwide.
\end{abstract}

Keywords: biotechnology, goat, IVP, LOPU, oocyte.

\begin{abstract}
Resumo
Independentemente se a coleta de oócitos é parte de um programa de produção in vitro de embriões (PIVE) e/ou promoverá avanços biotecnológicos como clonagem e transgênese, os aspectos metodológicos nas técnicas de recuperação de oócitos são imprescindíveis. Para alcançar sucesso de forma ótima, número suficiente de oócitos de boa qualidade é pré-requisito para diversas técnicas reprodutivas e a colheita de oócitos por laparoscopia $(\mathrm{COL})$ é a técnica recomendada para obtê-los de cabras saudáveis. Entretanto, a variabilidade na quantidade e qualidade de oócitos coletados ainda limita o uso desta tecnologia em grande escala. Sob as condições atuais, uma grande variação é relatada na literatura com taxas de recuperação de oócitos variando de 40 a $90 \%$ e o número de estruturas coletadas por fêmea entre 4 e 14 oócitos em diferentes laboratórios. Esta variabilidade pode ocorrer tanto em função de variáveis não controláveis, como raça, idade e características intrínsecas da cabra, como devido a aspectos controláveis, como o tratamento superestimulatório, tipo da agulha, pressão de aspiração, dentre outros. Acredita-se que novas pesquisas devam contribuir significativamente para a melhoria da técnica de COL. Esta revisão objetiva relatar os diferentes fatores que influenciam a resposta de cabras doadoras após COL, apresentando as principais etapas para recuperação oocitária assim como modificações técnicas propostas para melhoria da eficiência da COL. Além disso, discutir sobre potencias aplicações de oócitos caprinos depois de sua recuperação por $\mathrm{COL}$ e resultados gerais sobre a técnica no mundo.
\end{abstract}

Palavras-chave: biotecnologia, caprino, PIV, LOPU, oócito.

\section{Introduction}

Animal biotechnology is one of the fields of science that has provided the most spectacular discoveries in the last two decades, from the sheep Dolly, to transgenic pigs that can be organ donors for humans, and to animal bioreactors producing human therapeutic proteins in milk (Reviewed by Duszewska et al., 2010). The potential application of in vitro embryo production
(IVP), cloning or transgenesis depends on the development of reliable, repeatable and efficient techniques for recovery of good quality oocytes, among other factors (Mermillod et al., 2006; Galli et al., 2000; Gibbons et al., 2008; Souza-Fabjan et al., 2014). In order to recover oocytes, earlier reports have used ovariectomy via laparotomy (Younis et al., 1991; Keskintepe et al., 1994). Another possibility was the use of laparotomy, where the oocytes were aspirated from intact ovaries (Ptak

*Recebido em 2 de novembro de 2013 e aceito em 17 de março de 2014.

**INRA, UMR7247, Physiologie de la Reproduction et des Comportements, INRA, CNRS, Université de Tours, Haras Nationaux. 37380 Nouzilly, France.

*** Laboratory of Physiology and Control of Reproduction, Veterinary School, State University of Ceará, Av. Dedé Brasil, 1700, 60740-90, Fortaleza, CE, Brazil.

**** Museum National d'Histoire Naturelle, Réserve de la Haute Touche, 36290, Obterre, France. 
et al., 1999a), but this technique could lead to development of adherences. Studies involving slaughtered healthy goats were also published (Crozet et al., 1995; Cognié et al., 2004). However, unless any organizational reason aiming to reduce the herd is involved (Katska-Ksiazkiewicz et al., 2007) or as a part of the experimental design (Vazquez et al., 2010), this method is ethically unacceptable nowadays in healthy females. In cattle, the transvaginal ultrasound-guided ovum pick-up (tvOPU) technique is currently the most used to successfully and repeatedly obtain oocytes (Viana et al., 2004; Bols, 2005). However, in goats, Graff et al. (1999) obtained lower numbers of oocytes from females submitted to tvOPU as compared to those submitted to laparoscopy (4.3 vs. 11.5 oocytes collected per doe).

Currently, goat oocytes are mostly collected from slaughterhouse ovaries or, less often, by laparoscopic ovum pick up (LOPU) from live animals. Slaughterhouse ovaries may provide a cheap and relatively abundant source of oocytes by follicles aspiration, slicing or follicle dissection (Martino et al., 1994). These oocytes from unknown females are helpful for research. However, in diverse countries, the number of goats slaughtered is reduced and consequently it is difficult to carry out proper experiments using their ovaries (Tan et al., 2011). Therefore, LOPU may be an alternative and used as an important source of oocytes. Moreover, the use of IVP for genetic improvement or diffusion requires collecting oocytes from given females with high economic or genetic merit. This could be done after accidental culling of the female or at the end of her life to ensure a last reproduction or from living female, through LOPU (Mermillod et al., 2006). LOPU procedure is less stressful, less invasive, lasts less (each session takes between 10 and 20 min per does) than laparotomy and can be repeated at short intervals without distressing animals or altering oocyte developmental competence. It is noteworthy that after repeated LOPU in sheep no complication such as adhesions and fibroses occurred and normal histology of ovaries were observed (Teixeira et al. 2011), confirming that laparoscopy is a minimally invasive procedure. Therefore, LOPU is the recommended technique for obtaining good-quality oocytes from live donors (Baldassarre and Karatzas, 2004; Pierson et al., 2004; Baldassarre et al., 2007). Besides, LOPU-IVP programs are particularly well designed for amplification of endangered breed or species for which few genitors are available.

Whether we are collecting oocytes from valuable donors as part of an IVP program, or oocytes are being collected from standard goats to be used as recipient cytoplasts in a somatic cell nuclear transfer (SCNT) program, reproductive success rates depend on LOPU technique efficiency (Baldassarre, 2012). The development of LOPU began in the 1990s and there is still little information available on immature oocytes collected from live goats and their subsequent IVP. In addition, despite heavy research efforts, the variability of the number and quality of the oocytes collected still limits the large-scale use of this technology. Under the current conditions, oocyte recovery rates range from 40 to $90 \%$, and the number of harvested oocytes per female between 4 and 14, in different laboratories (Baldassarre and Karatzas, 2004; Pierson et al., 2004; Gibbons et al., 2007).

This variability may depend either on intrinsic variables related with the donor, such as breed, age, individual response or on aspects that can be controlled, such as stimulation treatment, type of needle, aspiration pressure, among others. This review will focus on: i, different factors influencing goat donor response in LOPU; ii, the main steps for oocyte recovery as well as technical alternatives for improving LOPU efficiency; iii, the potential applications of goat oocytes after their recovery by LOPU; and iv, overall results in goat IVP worldwide.

\section{Before LOPU - Hormonal treatment and other factors affecting ovarian response}

\section{Hormonal protocols for ovarian stimulation}

Different schemes of hormonal stimulation have been evaluated in order to improve the quantity, quality and developmental competence of oocytes from does submitted to LOPU (Avelar et al., 2008; Baldassarre and Karatzas, 2004; Gibbons et al., 2008). The goats should be heat synchronized and stimulated with gonadotropins. These protocols enable synchronous recruitment of a large population of follicles. Progestagen (or progesterone) releasing devices are employed for estrus synchronization during 10 to $14 \mathrm{~d}$ and they are usually left in the vagina until the moment of follicles aspiration in order to avoid ovulations. Indeed, a dose of prostaglandin F2 $\alpha$ analogue is used to promote luteolysis of corpus luteum present and secreting endogenous progesterone. Hormonal treatments for ovarian stimulation proposed by different research groups worldwide in goats are represented in Figure 1. The use of $\mathrm{GnRH}$ analogue for one week prior to the stimulatory regime in goats adversely affected both the number of follicles available and oocytes recovered by LOPU (Baldassarre et al., 2001), whereas similar treatment may be helpful in sheep (Cognié et al., 2004).
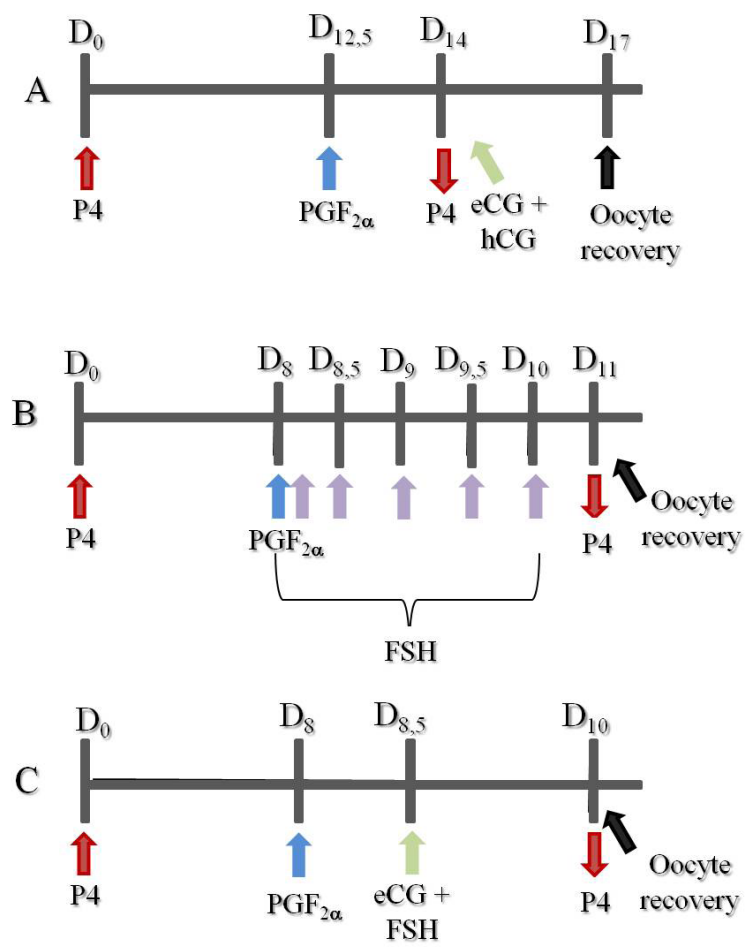

Figure 1: Stimulation treatments proposed by different research groups for LOPU in goat using A: eCG associated to $\mathrm{hCG}, \mathrm{B}$ : five doses of FSH or C: eCG associated to FSH, called "one shot". A. P4 = CIDR, PGF2 $\alpha=125 \mu \mathrm{g}$ cloprostenol, eCG = $1500 \mathrm{IU}, \mathrm{hCG}=250 \mathrm{IU}$, (Tan et al., 2011); B. P4 = 60 mg MAP, PGF2 $\alpha=50 \mu \mathrm{g}$ cloprostenol, $\mathrm{pFSH}=30 / 30 / 20 / 20 / 20 \mathrm{mg}$ (Avelar et al., 2012); C. P4 $=60 \mathrm{mg}$ MAP, PGF2 $\alpha=125 \mu \mathrm{g}$ cloprostenol, eCG $=300$ $\mathrm{IU}, \mathrm{pFSH}=80 \mathrm{mg}$ (Baldassarre and Karatzas, 2004) 
It is well described that FSH stimulation prior to oocyte recovery increases oocyte production efficiency with significantly more follicles punctured and oocytes retrieved from each female (Katska-Ksiazkiewicz et al., 2004). Porcine derived-FSH (pFSH; 20 vs $40 \mathrm{mg}$ ) and $\mathrm{FSH}$ of equine origin (eFSH; 20 vs $40 \mathrm{mg}$ ) were compared. Goats that received $40 \mathrm{mg} \mathrm{pFSH}$ allowed the recovery of 14.8 oocytes per doe, greater $(P<0.05)$ than 10.5 when they received $40 \mathrm{mg}$ eFSH or 6-7 oocytes when only $20 \mathrm{mg}$ p/eFSH were administered (Graff et al., 1999). Generally, a greater FSH stimulation dose for donor females produces more large follicles which are easier to visualize and aspirate (Graff et al., 1999). It was observed that does receiving high dose of ovine FSH (1 IU) had greater proportion of zygotes reaching the blastocyst stage than goats treated with half dose (Locatelli et al., 2004). However, interestingly, Katska-Ksiazkiewicz et al. (2004) reported a lower cleavage rate in FSH-stimulated goats rather than in the control group, but this difference was balanced by the higher rate of development to the blastocyst stage in the FSH-treated group. Morton et al. (2005) reported a similar embryo production rate in ewes submitted to treatment with FSH vs. without FSH prior to LOPU. In fact, although not statistically different, when we consider the ewes that received $\mathrm{FSH}$ they had a lower cleavage rate $(\sim 59 \%)$ with respect to non treated ewes $(\sim 79 \%)$. To summarize, these data suggest that FSH may enhance the amount of oocytes recovered per doe, however, some reports indicate an adverse effect on cleavage rate although it affects positively blastocyst development rate. Some of the additional oocytes recruited by FSH treatment may be of low quality and unable to cleave.

The positive or negative effect of FSH may be in relation to its administration scheme. Ewes treated with decreasing doses of $\mathrm{FSH}$ administered at $12 \mathrm{~h}$ interval, presented a higher number of large follicles $(>5 \mathrm{~mm}$ ) than those submitted to constant doses (4 doses of $24 \mathrm{IU}$ every $12 \mathrm{~h}$ ). Blastocyst rates were similar for untreated ewes $(13.7 \%)$ or those treated with decreasing FSH doses $(11.8 \%)$, but were greater for ewes treated with a constant FSH dose (20.4\%). A possible explanation for the lower embryo development capacity in FSH treatment in decreasing doses could be that the first two very high doses could have induced to a rapid and abnormal follicular development (Berlinguer et al., 2004). With regard to the number of doses, the higher number of FSH injections ( 5 vs. 3 ) resulted in Grade $1 / 2 \mathrm{COC}$ with higher Epidermal Growth Factor Receptor expression in cumulus cells, that correlated with an elevated meiotic competence following in vitro maturation (IVM) in goats (Almeida et al., 2010). Current treatments mostly consist in multi-injection $\mathrm{FSH}$ regimen, but the protocols are very labor intensive and rather stressful to animals because of excessive handling. Therefore, the "one shot" regime, in which a combination of FSH and eCG is given as a single injection (Figure 1; treatment $\mathrm{C}$ ) may represent an alternative, which is less expensive and requires less labor input. Using this protocol, Baldassarre and Karatzqs (2004) have conducted 1580 LOPU procedures and have recovered 21,219 oocytes (13.4 oocytes per goat) representing an average recovery rate of around $80 \%$.

In general, LOPU is performed at $10,24,36$ or $48 \mathrm{~h}$ after the end of gonadotropin administration (Abdullah et al., 2008; Gibbons et al., 2008; Avelar et al., 2012). Stimulation with the one shot treatment has been carried out at 24,36 or $48 \mathrm{~h}$ before LOPU (Gibbons et al., 2008). It was recently demonstrated that a prolonged interval from $\mathrm{FSH} / \mathrm{hCG}$ to LOPU improved oocyte retrieval rate and oocyte quality in goats. LOPU at 60 or $72 \mathrm{~h}$ after $\mathrm{FSH} / \mathrm{hCG}$ optimized yields of good quality oocytes for IVM and embryo production in comparison to $36 \mathrm{~h}$ interval (Abdullah et al., 2008).

\section{Individual characteristics}

Besides stimulation treatment, it is also important to consider intrinsic factors of donor goats, in particular the body condition score, breed, age, individual response, since they may influence the quality and number of oocytes obtained (Cognié et al., 2004). Surely, the individual ability of the goats to respond to superovulatory treatment would be one of the most important factors in the variability of the final effectiveness of the technique. For example, a very large variability was observed among individual response in cows within a range from 0 to 128 oocytes (Pontes et al., 2011) and in goats, ranging from 4 to 33 follicles and 2 to 12 oocytes recovered (Gibbons et al., 2007). Such variability shows that the individual response is one of the most critical points, which is difficult to overcome (Pontes et al., 2011).

\section{Age}

The use of prepubertal animals as oocyte donors is an interesting possibility, allowing to reduce the interval between generations and to accelerate the process of genetic improvement in selection schemes (Paramio, 2010). The effect of goat donors age on oocyte quality, as well as the effect of follicle size were reviewed (Paramio, 2010). Oocytes collected from prepubertal animals are less competent for development than those collected from adult goats (Mogas et al., 1997; Ptak et al., 1999). Moreover, ultrastructural and functional deficiencies are reported in prepubertal goat oocytes (Paramio, 2010). However, it has been recently shown that one real problem of prepubertal goats is that they have smaller follicles than adult ones, but the developmental competence of oocytes obtained from larger follicles $(\geq 3 \mathrm{~mm})$ was similar between prepubertal and adult goats (Romaguera et al., 2011). On the other hand, Baldassarre et al. (2007) demonstrated that LOPU-IVP could be successfully used to extend the reproductive life of valuable aged goats that have acquired difficulties becoming pregnant by artificial insemination after multiple pregnancies.

\section{Season}

The season could also influence the quality of LOPU oocytes. Regarding the season studied, the number of aspirated follicles was similar, whereas the proportion of good quality COC (Grade I/II) was enhanced in the breeding season in goats. However, interestingly, the cleavage rate of LOPU oocytes and blastocyst development rate of slaughterhouse oocytes were both higher in the anestrous season (our unpublished data). Similarly, season was shown to affect the number and competence of recovered oocytes in sheep and cleavage rate tended to be higher in the anestrous season (oocytes recovered from ovaries obtained after euthanasia) (Vazquez et al., 2010). Recently, oocyte developmental competence in buffalo was also shown to be affected by season since higher cleavage and embryo yields were recorded in autumn compared to spring, with intermediate results in summer and winter (Di Francesco et al., 2011). In cattle, the number of follicles and collected oocytes decreased significantly during the hot season, only in empty Japanese 
black cows. It is noteworthy that pregnant cows showed a significantly higher proportion of cleavage, blastocyst rate and freezable embryos than empty cows (Takuma et al., 2010). In ewes, a subcutaneous implant of melatonin improved oocyte developmental competence during the anestrous season (Vazquez et al., 2010). Therefore, there are some technical approaches that could be used to overcome the season effect.

\section{Breed}

In cattle, Pontes et al. (2010) reported a large-scale commercial program for IVP from dairy donors. The number of viable oocytes per OPU session was 12.1 (Gir), 8.0 (Holstein), 16.8 (1/4 Holstein x 3/4 Gir), and 24.3 (1/2 Holstein-Gir crossbred), significantly different among breeds, with no prior stimulation. An indirect influence of the breed is the pattern of ovaries concerning their size. It was observed in sheep that larger ovaries yielded a higher number of oocytes in comparison with smaller ovaries (Wani et al., 1999).

\section{Interval of $\angle O P U$}

The time between LOPU in successive treatments varies between 4 and 16 days. With respect to the use of successive procedures in the same doe, various authors have pointed out that it affects neither the quantity of ovarian follicles nor the quality of the oocytes obtained (Gibbons et al., 2008). In cattle, there is a general agreement that twice-weekly aspiration yields a higher number of viable oocytes and transferable embryos considering both sessions than once-weekly aspiration, since it doubles the frequency of follicular waves, which become uncoupled from the estrous cycle because of inhibition of ovulation (Boni, 2012). However, there is no study in goats using this system and the most similar work was reported by Gibbons et al. (2007), in which LOPU was performed every four days, with three sessions within eight days. The authors found no significant differences in follicular development and oocyte quality between the three successive LOPU sessions.

\section{During LOPU - The procedure and latest improvements}

\section{The procedure}

The females should be deprived of food and water for $36 \mathrm{~h}$ and $24 \mathrm{~h}$, respectively, prior to laparoscopy (Avelar et al., 2012). The surgical field, cranial to the udder, should be shaved and disinfected. In goat, efficient sedation and anesthesia with xylazine and ketamine (Avelar et al., 2012) or thiopental and continuous infusion of isoflurane through inhalation (Souza-Fabjan et al., 2013) for adequate immobilization are essential for successful aspiration. Commonly, the donor is placed in an inverted position on a cradle at a $45^{\circ}$ angle, in order to prevent organs perforation when trocars are inserted into the abdomen (Silva et al., 2012) (Figure $2 A)$. Local administration of lidocaine is applied to the puncture sites of the trocars and three small incisions $(3-5 \mathrm{~mm})$ are made with a scalpel (Figure 2B). An endoscope is inserted into the abdominal cavity through a trocar, cranial to the udder and to the left of the midline. This trocar is connected to a $\mathrm{CO}_{2}$ tank allowing to insufflate the abdominal cavity with $\mathrm{CO}_{2}$. Once the abdominal cavity is expanded, a second trocar is inserted into the right side (opposite from the first one) of the abdomen for introduction of an atraumatic grasping forceps. The uterine horns are gently manipulated to allow visualization of each stimulated ovary (Figure $3 \mathrm{~A}$ ). The atraumatic grasping forceps is used to stabilize the mesovarium, making possible for the technician to turn the ovary in different directions for better positioning, visualization, and follicle aspiration. To prevent damages, grasping of the ovarian vascular pedicle should be performed carefully and excessive torsion should be avoided. The last trocar is inserted in the midline for passing oocyte aspiration needle. The objective is to enter the follicle from the side, with the needle in a direction parallel to the base of the follicle, or if not possible, puncture should be perpendicular to the follicle wall. Once the needle is inside the follicle, it must be gently rotated to ensure that as much of the follicle contents as possible is aspirated (Baldassarre et al., 1994) (Figure 3B). In cattle, this technique showed a significant improvement of approximately $30 \%$ of the recovery rate (Sasamoto et al., 2003) due to a better detachment of the COC by curettage of the follicular wall during follicle aspiration. Observation of the vessels on the follicle wall during laparoscopy makes possible to choose a less vascular site to introduce the needle, and aspirating follicular fluid containing little or no blood. All follicles of more than $2 \mathrm{~mm}$ of diameter, visible on the surface of the ovaries, are aspirated using a needle connected to an aspiration and flushing system. It is noteworthy that if the follicle is too big, comparable to the size of a cyst (varies according to breed), the aspiration should not be performed to the collection tube. The use of heparin is essential both in the aspiration medium (usually buffered TCM 199) and in the periodic washing of the circuit to prevent coagulation and blockage of the system. Finally, the trocar orifices are treated with a local antibiotic-cicatrizing solution. The collection tube containing aspirated fluid (3-5 mL) with COC is dispensed into a sterile Petri dish (90 or $100 \mathrm{~mm}$ ) for COC searching under a stereomicroscope at $35-37^{\circ} \mathrm{C}$ (Tan et al., 2011; Avelar et al., 2012; Silva et al., 2012). Some small differences were reported such as the use of a discard cannula for intrauterine artificial insemination called "Aspic for pellet insemination in sheep" for follicle puncture in sheep and goat donors (Gibbons et al., 2007).

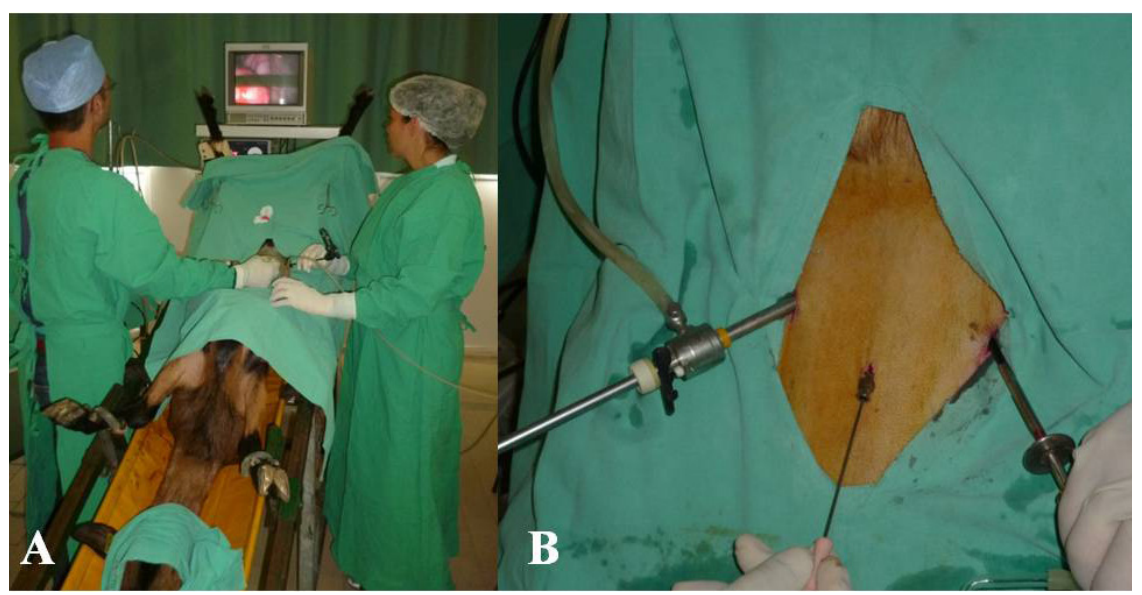

Figure 2: A. General view of LOPU system in goat. B. View of three trocars position during LOPU. 


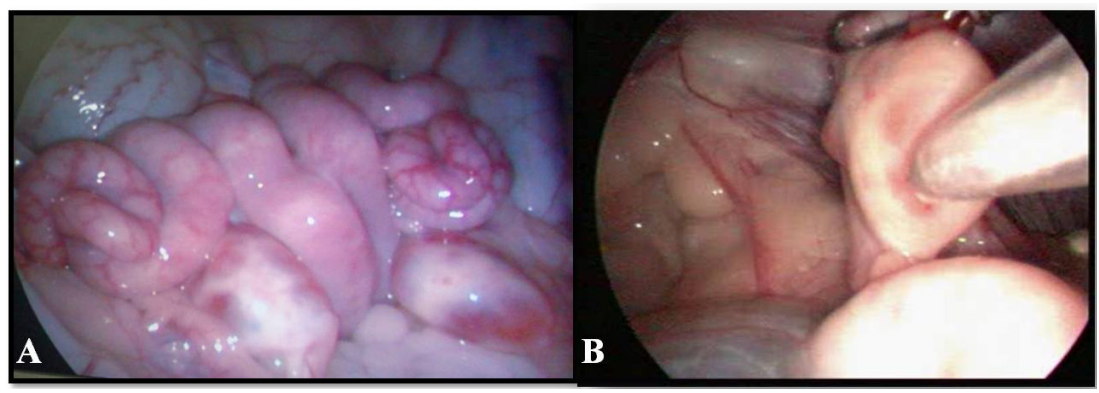

Figure 3: A. Reproductive tract of a goat showing both ovaries with high response to stimulation, i.e., follicles available for puncture. B. Follicle aspiration through specific needle for LOPU diameter tubing were significantly more effective in terms of proportion of good quality oocytes, probably due to less turbulence when the oocyte passed from the needle to the tubing (overall efficiency rates: $34.9,32.3$ and $28.1 \%$ for 1,2 and $3 \mathrm{~mm}$ respectively) (Rodriguez et al., 2006).

\section{Aspiration pressure}

Aspiration pressure is another factor influencing both recovery rate and oocyte quality. The vacuum connected to the needle is regulated from 25 to $70 \mathrm{mmHg}$ for goats. Our group demonstrated that the pressure of $30 \mathrm{mmHg}$ in

\section{Important aspects for achieving high recovery rate}

The effectiveness of this technique is based on the quantity and quality of the oocytes recovered. Besides the stimulation treatment, high variability in the results may be due to follicle size as well as type of needle, aspiration pressure and flow rate (Gibbons et al., 2008). The aspiration conditions used during LOPU are extremely important considering the COC structure, while optimizing their recovery rate (oocytes recovered/follicles punctioned) (Bols et al., 1997), a lesser proportion of good quality $\mathrm{COC}$ is recovered. Briefly, some considerations with respect to these factors are described below.

\section{Follicle size}

Follicle size does not affect recovery rate, but proportion of good quality oocytes was higher for large (77.9\%) and medium (64.4\%) follicles than for small follicles in sheep (Rodriguez et al., 2006). Crozet et al. (1995) observed that COC obtained from big follicles have better in vitro maturation than those from small follicles in goats. Commonly, a direct relationship between follicle size, oocyte diameter and developmental capacity has been reported (Romaguera et al., 2011).

\section{Needle and tubing}

Regarding the type of needle, the variables are the diameter of the needle and the length of the bevel. The diameter could modify the quality of the oocytes, since a smaller needle diameter would submit the oocyte to shearing forces, which could remove some of the cumulus cells. The bevel determines the portion of the needle that is introduced into the follicle to detach and aspirate the oocyte, directly affecting the percentage of retrieval (Bols et al., 1997).

In bovine, higher recovery rates were obtained with wider diameter needles $(18 \mathrm{G}$ ) in comparison with 19 and $21 \mathrm{G}$ needles (Bols et al., 1997). However, Rodriguez et al. (2006) reported that needle gauge did not affect aspiration device efficiency in sheep. Various authors used different diameters of needles varying from 16 to $23 \mathrm{G}$, obtaining good results for recovery and oocyte quality (Gibbons et al., 2008), but no studies were found in the literature comparing different needle diameters for LOPU in goats. Our group observed that $18 \mathrm{G}$ needle promoted a significant better oocyte recovery rate in goats than a $20 \mathrm{G}$ needle, whereas no influence was noted on oocyte quality (unpublished data).

Moreover, short needles produced the best results for aspiration, because of the short passage from the follicle to the silicon tubing, which is less traumatic for the oocyte than the steel needle (Rodriguez et al., 2006). Interestingly, thin and intermediate goats was efficient and reached high recovery rate (84\%). The optimal aspiration flow using a vacuum pump for goats is between 50 and 70 drops $\min ^{-1}$ (Baldassarre et al., 2003a; Koeman et al., 2003). It was earlier reported that low pressures such as 25 $\mathrm{mmHg}$ showed low rates of recovery in sheep (Alberio et al., 2002) and high as $100 \mathrm{mmHg}$ resulted in lesser proportion of good quality COC (Morton et al., 2008).

It should be noted that it is possible to reduce and simplify the cost of LOPU, by using conventional syringes adapted for this purpose instead of specially designed material. It is also possible to use a cannula for intrauterine artificial insemination in sheep and goats without vacuum control (Gibbons et al., 2007).

In cattle, tvOPU demands tubing of greater length and thus requiring higher vacuum. For all needle types, more oocytes were recovered at higher aspiration pressures. On the other hand, the proportion of oocytes surrounded by compact cumulus and in vitro produced blastocysts decreased progressively as vacuum increased (Bols et al., 1997). It is noteworthy that high vacuums, although resulting in high recovery rates, can affect quality of the oocytes recovered (Cognié et al., 2004). As mentioned below, most part of the studies evaluating aspiration pressures have focused on the collection of oocytes, and have defined the optimal oocyte aspiration pressure based on the number/quality of oocytes recovered. Furthermore, the aspiration pressure during oocyte recovery may affect subsequent embryonic development in vitro (Tervit, 1996). The optimal aspiration pressure for oocyte recovery may not be the optimal pressure for embryo development, but the literature focusing this point is very scarce in goats.

\section{Aspiration flow rate}

Narrow needles have lower flow rates than wide ones, for the same aspiration pressure. The aspiration flow rate measured in $\mathrm{mL}$ water/min allows achieving uniformity when using any combination of elements for LOPU. Aspiration flow rate significantly affects the proportion of good quality oocytes in sheep $(69.5,50.5,44.8,36.5$ and $28.3 \%$ for flows of $10,20,30,40$ and $50 \mathrm{~mL} / \mathrm{min}$ respectively) (Rodriguez et al., 2006). Moreover, the best LOPU devices differ for each follicle size. Small $(<3 \mathrm{~mm})$ and medium follicles (3-5 $\mathrm{mm}$ ) need low-aspiration flow rates and thin tubing for optimal results. On the contrary, pre-ovulatory and large follicles $(>5 \mathrm{~mm}$ ) showed best rates when aspiration flow was high and tubing was wide (Crozet et al., 1995). Fluid flow of 7 to $7.5 \mathrm{~mL} / \mathrm{min}$ was used in goats and the percentage of good quality oocytes was approximately $70 \%$ (Avelar et al., 2012). Depending of all these factors already mentioned the success of this technique could be greater or lesser. 


\section{After LOPU - Applications and potential}

LOPU is a reliable and effective technique for the recovery of goat oocytes for production of zygotes that may be DNA microinjected in order to obtain efficient transgenesis rates (Baldassarre et al., 2003). The same group also produced cloned live kids in a nuclear transfer program by the use of LOPU oocytes (Baldassarre et al., 2003b). Intracytoplasmic sperm injection (ICSI) was also performed in LOPU derived oocytes in goats (Abdullah et al., 2008). Another perspective for their use was reported by Cox et al. (2002) when they transferred oocytes to inseminated does generating a model to study sperm function in vivo. LOPU efficiently resets the $>2 \mathrm{~mm}$ diameter follicular population to zero and suppress dominant(s) follicle(s) effect which in turn guarantees that the new population will be uniformly renewed with less atresia. By performing OPU in cattle $24 \mathrm{~h}$ prior to superovulatory treatment, an improved efficiency of superovulatory response was found (Boni, 2012). This association could be also important in goats. Finally, an interesting area of biotechnology is the production of chimeras, which are individuals originated from more than one zygote by aggregation of two early-stage embryos. The production of chimera allows to verify pluripotency of blastomeres and to follow the differentiation process in prenatal development (Duszewska et al., 2010).

Currently, LOPU is implicitly associated to IVP in goat. Most part of research papers published in two different worldwide databases (pubmed and scopus) refers to the use of LOPU oocytes for IVP. Through consulting journals indexed by both databases, it is possible to estimate that approximately only 10 countries work with LOPU in goats in the world: United States of America (Graff et al., 1999), Chile (Cox et al., 2002; Cox and Alfaro, 2007), Canada (Baldassarre et al., 2003b; Pierson et al., 2004; Baldassarre et al., 2007), Argentina (Gibbons et al., 2007), Bangladesh (Rahman et al., 2007), Malaysia (Abdullah et al., 2008; Tan et al., 2011), France (Locatelli et al., 2004), Italy (Leoni et al., 2009), Brazil (Almeida et al., 2010; Avelar et al., 2012) and Spain (Morato et al., 2011). IVP involves four major steps: oocyte collection, oocyte in vitro maturation (IVM), in vitro fertilization (IVF) and in vitro development (IVD) of the resulting embryos up to the blastocyst stage, at which these embryos can be cryopreserved or transferred into the uterus of synchronized recipient females. These steps will be briefly detailed (SouzaFabjan et al., 2014).

After successful oocytes recovery COC are classified according to the number of cumulus cells layers and good quality COC (Grade 1 and 2) are submitted to IVM. One classification well accepted is: Grade 1 - Multilayered compact cumulus and finely granulated oocyte cytoplasm; Grade 2 - One to three layers of cumulus cells and finely granulated oocyte cytoplasm; Grade 3 - Incomplete or no cellular investment or heterogeneous oocyte cytoplasm and Grade 4 - Oocyte with abnormal shape and heterogeneous oocyte cytoplasm or apoptotic oocytes in jelly-like cumulus-corona cells investment (Avelar et al., 2012).

Our group observed that slaughterhouse oocytes had greater cleavage rate than LOPU oocytes, both after IVM in more complex medium: TCM-199 supplemented with follicular fluid (FF) and oFSH (89.5\% vs. $64.5 \%$, respectively); or under more simple medium, EGF and cysteamine $(87.5 \%$ vs. $37.3 \%$, respectively). For LOPU oocytes, both cleavage and blastocyst development rates increased significantly when FF-oFSH was used (Locatelli et al., 2008). These data clearly indicate that oocytes requirements during IVM may differ according to their origin. It remains unclear if their difference in terms of response to IVM treatments may be related to FSH stimulation prior to LOPU session or to post mortem changes in oocyte responsiveness in slaughterhouse group. Some interesting results have been obtained in cattle by targeting upstream of MPF activation, such as phosphodiesterase 3 , the enzyme which regulates cAMP level in cumulus cells, and in turn MPF activation in the oocyte (Gilchrist and Thompson, 2007). This more physiological inhibition process is able to increase final oocyte intrinsic quality before gonadotropin addition allowing meiotic resumption (Souza-Fabjan et al., 2014). Regarding IVM physical conditions, literature does not vary considerably and it is usually performed incubating $\mathrm{COC}$ in large groups under $5 \% \mathrm{CO}_{2}$ in air at 38 to $39^{\circ} \mathrm{C}$ with maximum humidity for $22-27 \mathrm{~h}$. IVM is commonly performed using tissue culture media enriched with amino acids and glucose, supplemented with hormones and heat inactivated serum (Souza-Fabjan et al., 2014).

After the step of IVM, the matured oocytes should undergo IVF. Either fresh or frozen-thawed semen can be used to fertilize matured oocytes. In any case, it is essential to improve live sperm cells proportion, usually by the use of Percoll or swim-up separation (Khatun et al., 2011). The most widely used medium is the modified synthetic oviduct fluid (SOF), supplemented by serum, antibiotics and other substances, varying according to the laboratories. The inclusion of heparin as capacitating agent in the fertilization medium significantly improves IVP in goats (Souza et al., 2013). Regarding IVF conditions for goats, sperm concentrations vary from 1 to $3.5 \times 10^{6} \mathrm{cells} / \mathrm{mL}$ and large groups of oocytes are co-incubated for $16-20 \mathrm{~h}$ at 38 to $39^{\circ} \mathrm{C}$ in humidified atmosphere of $5 \% \mathrm{CO}_{2}$ in air (Cognié et al., 2004). Some recent sheep IVF data show that sex-sorted spermatozoa induce equal or greater cleavage and blastocyst rates than nonsorted ones (de Graaf et al., 2009) and a large-scale commercial program for IVP in cattle using sexed sperm has been performed (Pontes et al., 2010). Despite its interesting applicability, up to now there are no reports related to the use of sexed spermatozoa in goat IVF.

The last step in order to produce in vitro embryos is the IVD, which occurs immediately after the end of IVF. We recently showed that oocytes should be denuded after IVF (Souza et al., 2013), washed and placed in an embryo culture medium that allows the development up to a stage that is compatible with their transfer to recipient uterus. The SOF medium supplemented with bovine serum albumin (BSA) and fetal calf serum has been successfully used for goats (Cognié et al., 2004) and embryos are usually cultured in droplets of IVD medium overlaid with mineral oil $(1 \mu \mathrm{L} /$ embryo). This relation medium/embryo is particularly important when working with LOPU, since a high variation in female response can be observed, and often the number of embryos per female remains low. The use of co-culture systems to mimic natural embryo environment in vitro may allow the improvement of embryo development, restore normal metabolic parameters, increase embryo viability and cryoresistance (Mermillod et al., 2010). The presumptive zygotes are incubated at 38 to $39^{\circ} \mathrm{C}$ in a humidified atmosphere of $5 \% \mathrm{O}_{2}, 5 \% \mathrm{CO}_{2}$ and $90 \% \mathrm{~N}_{2}$. After 6 to 8 days, the developed embryos can be transferred to recipients or cryopreserved (Cognié et al., 2004). Whereas the success 
of IVD is relatively high ( 40 to $50 \%$ of the initial oocytes finally reach the blastocyst stage) (Souza et al., 2013), the resulting embryos differ from in vivo derived ones on many aspects (gene expression, metabolism, morphology), resulting in a lower viability (Mermillod et al., 2006; Paramio, 2010), especially a lower resistance to different cryopreservation methods. However, the co-culture of embryos with caprine or bovine oviduct epithelial cells has been shown to improve both embryo production rate and quality of IVP embryos in goat (Rodriguez-Dorta et al., 2007). Our group recently demonstrated that it was possible to enhance the number of blastocysts by some modifications on goat IVF system, reaching up to $54 \%$ of initial oocytes developing to the blastocyst stage (Souza et al., 2013).

\section{Conclusions}

Successive collections by laparoscopy have demonstrated the feasibility of obtaining high numbers of good quality oocytes for
IVP, cloning or transgenesis. It is noteworthy that laparoscopy is a minimal invasive procedure, not perforating any organ of the reproductive system, as it happens when using ultrasoundguided OPU in cattle. However, it is still necessary to evaluate the best combination of variables considering the diameter of needle, aspiration pressure and flow rate, recovery percentage, oocyte quality and its competence to development for the more efficient use of LOPU in goats. Under the current conditions, too large variability is reported in response of females to hormonal stimulation treatment and $\mathrm{COC}$ recovery rates. Depending on all the factors listed in this review, related to donor intrinsic characteristics and procedures used, the success of this technique will be greater or lesser. Limits to LOPU application are still represented by lower pregnancy rate of in vitro vs. in vivo produced embryos, however, maternal environment mimicking by in vitro coculture systems could improve the viability of IVP embryos. We believe that new investigations should contribute to significant improvement of LOPU method in goats and sheep.

\section{Acknowledgments}

J.M.G. Souza-Fabjan was supported by CAPES, CNPq and Ceará State University. The authors wish to thank CAPES-COFECUB bilateral framework for financial support of collaboration between the Ceará State University and INRA on goat IVP (Grant 728/11, 2011-2013). This work was supported by a grant from Région Centre, France (PIVER program, \#200800030493, 2008-2011).

\section{References}

ABDULLAH, R.B.; LIOW, S.L.; RAHMAN, A.N.M.A; CHAN, W.K.; WAN-KHADIJAH, W.E.; NG, S.C. Prolonging the interval from ovarian hyperstimulation to laparoscopic ovum pick-up improves oocyte yield, quality, and developmental competence in goats. Theriogenology, v. 70, p. 765-771, 2008.

ALBERIO, R.; OLIVERA, J.; ROCHE, A.; ALABART, J.; FOLCH, $\mathrm{J}$. Performance of a modified ovum pick-up system using three different FSH stimulation protocols in ewes. Small Ruminant Research, v. 46, p. 81-87, 2002.

ALMEIDA, K.C.; PEREIRA, A.F.; ALCANTARA NETO, A.S.; AVELAR, S.R.; BERTOLINI, L.R.; BERTOLINI, M.; FREITAS, V.J.F.; MELO, L.M. Real-time qRT-PCR analysis of EGF receptor in cumulus-oocyte complexes recovered by laparoscopy in hormonally treated goats. Zygote, v. 19, p. 127-136, 2010.

AVELAR, S.R.G.; MOURA, R.R.; SOUSA, F.C.; PEREIRA, A.F.; ALMEIDA, K.C.; MELO, C.H.S.; TELES-FILHO, A.C.A.; BARIL, G.; MELO, L.M.; TEIXEIRA, D.I.A.; FREITAS, V.J.F. Oocyte production and in vitro maturation in Canindé goats following hormonal ovarian stimulation. Animal Reproduction, v. 9, p. 1-7, 2012.

BALDASSARRE, $H$. Practical aspects for implementing in vitro embryo production and cloning programs in sheep and goats. Animal Reproduction, v. 9, p. 188-194, 2012.

BALDASSARRE, H.; DE MATOS, D.G.; FURNUS, C.C.; CASTRO, T.E.; CABRERA FISCHER, E.I. Technique for efficient recovery of sheep oocytes by laparoscopic folliculocentesis. Animal Reproduction Science, v. 35, p. 145-150, 1994.

BALDASSARRE, H.; KEEFER, C.; GAUTHIER, M.; BHATIA, B.; BEGIN, I.; PIERSON, J.; LAURIN, D.; TRIGG, T.; DOWNEY, B.R.; KARATZAS, C.N. Laparoscopic ovum pick up and zygote recovery in goats treated with deslorelin implants before superovulation. Theriogenology, v. 55, p. 510, 2001.

BALDASSARRE, H.; KEEFER, C.; WANG, B.; LAZARIS, A.; KARATZAS, C.N. Nuclear transfer in goats using in vitro matured oocytes recovered by laparoscopic ovum pick-up. Cloning and stem cells, v. 5, p. 279-285, 2003a.
BALDASSARRE, H.; RAO, K.M.; NEVEU, N.; BROCHU, E.; BEGIN, I.; BEHBOODI, E.; HOCKLEY, D.K. Laparoscopic ovum pick-up followed by in vitro embryo production for the reproductive rescue of aged goats of high genetic value. Reproduction, fertility, and development, v. 19, p. 612-616, 2007.

BALDASSARRE, H.; WANG, B.; KAFIDI, N.; GAUTHIER, M.; NEVEU, N.; LAPOINTE, J.; SNEEK, L.; LEDUC, M.; DUGUAY, F.; ZHOU, J.F.; LAZARIS, A.; KARATZAS, C.N. Production of transgenic goats by pronuclear microinjection of in vitro produced zygotes derived from oocytes recovered by laparoscopy. Theriogenology, v. 59, p. 831-839, 2003b.

BERLINGUER, F.; LEONI, G.; BOGLIOLO, L.; PINTUS, P.P.; ROSATI, I.; LEDDA, S.; NAITANA, S. FSH different regimes affect the developmental capacity and cryotolerance of embryos derived from oocytes collected by ovum pick-up in donor sheep. Theriogenology, v. 61, p. 1477-1486, 2004.

BOLS, P.E. Puncture of immature ovarian follicles in bovine assisted reproduction. Verh K Acad Geneeskd Belg,v. 67, p. 177202, 2005.

BOLS, P.E.; YSEBAERT, M.T.; VAN SOOM, A.; DE KRUIF, A. Effects of needle tip bevel and aspiration procedure on the morphology and developmental capacity of bovine compact cumulus oocyte complexes. Theriogenology v. 47, p. 1221-1236, 1997.

BONI, R. Ovum pick-up in cattle: a $25 \mathrm{yr}$ retrospective analysis. Animal Reproduction, v. 9, p. 362-369, 2012.

COGNIE, Y.; POULIN, N.; LOCATELLI, Y.; MERMILLOD, P. State-of-the-art production, conservation and transfer of in-vitroproduced embryos in small ruminants. Reproduction, fertility, and development, v. 16, p. 437-445, 2004.

COX, J.F.; ALFARO, V. In vitro fertilization and development of OPU derived goat and sheep oocytes. Reproduction in domestic animals, v. 42, p. 83-87, 2007.

COX, J.F.; ZAVALA, A.; SARAVIA, F.; RIVAS, C.; ALFARO, V. Fertilization efficiency of in vitro matured oocytes transferred to oviducts of inseminated goats: a model to assess in vivo fertilization performance of goat spermatozoa. Theriogenology, v. 58, p. 1-8, 2002. 
CROZET, N.; AHMED-ALI, M.; DUBOS, M.P. Developmental competence of goat oocytes from follicles of different size categories following maturation, fertilization and culture in vitro. Journal of reproduction and fertility, v. 103, p. 293-298, 1995.

DE GRAAF, S.P.; BEILBY, K.H.; UNDERWOOD, S.L.; EVANS, G.; MAXWELL, W.M. Sperm sexing in sheep and cattle: the exception and the rule. Theriogenology, v. 71, p. 89-97, 2009.

DI FRANCESCO, S.; BOCCIA, L.; CAMPANILE, G.; DI PALO, R.; VECCHIO, D.; NEGLIA, G.; ZICARELLI, L.; GASPARRINI, B. The effect of season on oocyte quality and developmental competence in Italian Mediterranean buffaloes (Bubalus bubalis). Animal reproduction science, v. 123, p. 48-53, 2011.

DUSZEWSKA, A.M.; TRZECIAK, P.; COMPA, A.; RAPAŁA, L. Selected issues concerning biotechnology of farm animals breeding - a review. Animal Science Papers and Reports, v. 28, p. 295-306, 2010.

GALLI, C.; CROTTI, G.; NOTARI, C.; TURINI, P.; DUCHI, R.; LAZZARI, G. Embryo production by ovum pick up from live donors. Theriogenology, v. 55, p. 1341-1357, 2001.

GIBBONS, A.; PEREYRA BONNET, F.; CUETO, M.; CATALA, M.; SALAMONE, D.; GONZÁLEZ-BULNES, A. Procedure for maximizing oocyte harvest for in vitro embryo production in small ruminants. Reproduction in Domestic Animals, v. 42, p. 423-426, 2007.

GIBBONS, A.; PEREYRA BONNET, F.; CUETO, M.I.; SALAMONE, D.; CATALA, M. Recovery of sheep and goat oocytes by laparoscopy. Acta Scientiae Veterinariae, v. 36, p. 223-230, 2008.

GILCHRIST, R.B.; THOMPSON, J.G. Oocyte maturation: Emerging concepts and technologies to improve developmental potential in vitro. Theriogenology, v. 67, p. 6-15, 2007.

GRAFF, K.J.; MEINTJES, M.; DYER, V.W.; PAUL, J.B.; DENNISTON, R.S.; ZIOMEK, C.; GODKE, R.A. Transvaginal ultrasound-guided oocyte retrieval following FSH stimulation of domestic goats. Theriogenology, v. 51, p. 1099-1119, 1999.

KATSKA-KSIAZKIEWICZ, L.; OPIELA, J.; RYNSKA, B. Effects of oocyte quality, semen donor and embryo co-culture system on the efficiency of blastocyst production in goats. Theriogenology, v. 68 , p. 736-744, 2007.

KATSKA-KSIAZKIEWICZ, L.; RYNSKA, B.; GAJDA, B.; SMORAG, $Z$. Effect of donor stimulation, frozen semen and heparin treatment on the efficiency of in vitro embryo production in goats. Theriogenology, v. 62, p. 576-586, 2004.

KESKINTEPE, L.; DARWISH, G.M.; YOUNIS, A.I.; BRACKETT, B.G. In vitro development of morulae from immature caprine oocytes. Zygote, v. 2, p. 97-102, 1994.

KHATUN, M.; BHUIYAN, M.M.; AHMED, J.U.; HAQUE, A.; RAHMAN, M.B.; SHAMSUDDIN, M. In vitro maturation and fertilization of prepubertal and pubertal black Bengal goat oocytes. Journal of veterinary science, v. 12, p. 75-82, 2011.

KOEMAN, J.; KEEFER, C.L.; BALDASSARRE, H.; DOWNEY, B.R. Developmental competence of prepubertal and adult goat oocytes cultured in semi-defined media following laparoscopic recovery. Theriogenology, v. 60, p. 879-889, 2003.

LEONI, G.G.; SUCCU, S.; SATTA, V.; PAOLO, M.; BOGLIOLO, L.; BEBBERE, D.; SPEZZIGU, A.; MARDEDDU, M.; BERLINGUER, F.; LEDDA, S.; NAITANA, S. In vitro production and cryotolerance of prepubertal and adult goat blastocysts obtained from oocytes collected by laparoscopic oocyte-pick-up (LOPU) after FSH treatment. Reproduction, Fertility and Development, v. 21,p. 901908, 2009.
LOCATELLI, Y.; POULIN, N.; BARIL, G.; TOUZE, J.L.; BOUTTIER, A.; COGNIE, Y.; MERMILLOD, P. FSH treatment before laparoscopic ovum pick-up in goat influences quantity and quality of recovered oocytes. Reproduction Fertility and Development, v. 16, p. 513, 2004.

LOCATELLI, Y.; POULIN, N.; BARIL, G.; TOUZE, J.L.; FATET, A.; BECKERS, J.F.; MERMILLOD, P. In vitro maturation treatment affects developmental competence of laparoscopic ovum pickupderived oocytes in follicle-stimulating hormone-stimulated goats. Reproduction Fertility and Development, v. 20, p. 182-183, 2008.

MARTINO, A.; PALOMO, M.J.; MOGAS, T.; PAMMIO, M.T. Influence of the collection technique of prepubertal goat oocytes on in vitro maturation and fertilization. Theriogenology, v. 42, p. 859-873, 1994.

MERMILLOD, P.; LOCATELLI, Y.; DALBIĖS-TRAN, R.; UZBEKOVA, S.; BARIL, G.; GUIGNOT, F.; PERREAU, C.; POULIN, N.; TOUZÉ, J.L.; PENNETIER, S.; SCHMALTZ, B.; COGNIÉ, Y. In Vitro Production Of Ruminant Embryos: Results, Limits And Perspectives. Symposium COA/INRA Scientific Cooperation in Agriculture, Tainan (Taiwan, R.O.C.), November 7-10, 2006.

MERMILLOD, P. ; SCHMALTZ, B.; PERREAU, C.; TSIKIS, G.; MARTINOT, E.; CORDOVA, A.; LOCATELLI, Y. Early development of ruminant embryos, autonomous process or the result of a positive dialog with surrounding maternal tissues? Acta Scientiae Veterinariae, v. 38, p. 521-533, 2010.

MOGAS, T.; PALOMO, M.J.; IZQUIERDO, M.D.; PARAMIO, M.T. Developmental capacity of in vitro matured and fertilized oocytes from prepubertal and adult goats. Theriogenology, v. 47, p. 11891203, 1997.

MORATO, R.; ROMAGUERA, R.; IZQUIERDO, D.; PARAMIO, M.T.; MOGAS, T. Vitrification of in vitro produced goat blastocysts: Effects of oocyte donor age and development stage. Cryobiology, v. 63, p. $240-244,2011$.

MORTON, K.M.; DE GRAAF, S.P.; CAMPBELL, A.; TOMKINS, L.M.; MAXWELL, W.M.; EVANS, G. Repeat ovum pick-up and in vitro embryo production from adult ewes with and without $\mathrm{FSH}$ treatment. Reproduction in Domestic Animals, v. 40, p. 422-428, 2005.

MORTON, K.M.; MAXWELL, W.M.C.; EVANS, G. Effect of Aspiration Pressure during Oocyte Harvesting on Oocyte Recovery and in vitro Development of Ovine Oocytes. Reproduction in Domestic Animals, v. 43, p. 106-110, 2008.

PARAMIO, M.T. In vivo and in vitro embryo production in goats. Small Ruminant Research, v. 89, p. 144-148, 2010.

PIERSON, J.; WANG, B.; NEVEU, N.; SNEEK, L.; COTE, F.; KARATZAS, C.N.; BALDASSARRE, H. Effects of repetition, interval between treatments and season on the results from laparoscopic ovum pick-up in goats. Reproduction, fertility, and development, v. 16, p. 795-799, 2004.

PONTES, J.H.F.; MELO STERZA, F.A.; BASSO, A.C.; FERREIRA, C.R.; SANCHES, B.V.; RUBIN, K.C.P.; SENEDA, M.M. Ovum pick up, in vitro embryo production, and pregnancy rates from a large-scale commercial program using Nelore cattle (Bos indicus) donors. Theriogenology, v. 75, p. 1640-1646, 2011.

PONTES, J.H.F.; SILVA, K.C.F.; BASSO, A.C.; RIGO, A.G.; FERREIRA, C.R.; G.M.G., S.; SANCHES, B.V.; PORCIONATO, J.P.F.; VIEIRA, P.H.S.; FAIFER, F.S.; STERZA, F.A.M.; SCHENK, J.L.; SENEDA, M.M. Large-scale in vitro embryo production and pregnancy rates from Bos taurus, Bos indicus, and indicus-taurus dairy cows using sexed sperm. Theriogenology, v. 74 , p. 13491355, 2010. 
PTAK, G.; DATTENA, M.; LOI, P.; TISCHNER, M.; CAPPAI, P. Ovum pick-up in sheep: efficiency of in vitro embryo production, vitrification and birth of offspring. Theriogenology, v. 52, p. 11051114, 1999a.

PTAK, G.; LOI, P.; DATTENA, M.; TISCHNER, M.; CAPPAI, P, Offspring from one-month-old lambs: studies on the developmental capability of prepubertal oocytes. Biology of Reproduction, v. 61, p. 1568-1574, 1999b.

RAHMAN, A.N.M.A.; ABDULLAH, R.B.; EMBONG, W.K.W. Goat embryo development from in vitro matured oocytes of heterogeneous quality through intracytoplasmic sperm injection technique. Biotechnology, v. 6, p. 373-382, 2007.

RODRIGUEZ-DORTA, N.; COGNIE, Y.; GONZALEZ, F.; POULIN, N.; GUIGNOT, F.; TOUZE, J.L.; BARIL, G.; CABRERA, F.; ALAMO, D.; BATISTA, M.; GRACIA, A.; MERMILLOD, P. Effect of coculture with oviduct epithelial cells on viability after transfer of vitrified in vitro produced goat embryos. Theriogenology, v. 68, p. 908-913, 2007.

RODRIGUEZ, C.; ANEL, L.; ALVAREZ, M.; ANEL, E.; BOIXO, J.C.; CHAMORRO, C.A.; DE PAZ, P. Ovum Pick-up in Sheep: a Comparison between Different Aspiration Devices for Optimal Oocyte Retrieval. Reproduction in Domestic Animals v. 41, p. 106113, 2006.

ROMAGUERA, R.; MOLL, X.; MORATO, R.; ROURA, M.; PALOMO, M.J.; CATALA, M.G.; JIMENEZ-MACEDO, A.R.; HAMMAMI, S.; IZQUIERDO, D.; MOGAS, T.; PARAMIO, M.T. Prepubertal goat oocytes from large follicles result in similar blastocyst production and embryo ploidy than those from adult goats. Theriogenology, $\mathrm{v}$. 76, p. 1-11, 2011

SASAMOTO, Y.; SAKAGUCHI, M.; KATAGIRI, S.; YAMADA, Y.; TAKAHASHI, Y. The effects of twisting and type of aspiration needle on the efficiency of transvaginal ultrasound-guided ovum pick-up in cattle. J Vet Med Sci, v. 65, p. 1083-1086, 2003.

SILVA, J.C.B.; OKABE, W.K.; TRALDI, A.S. From cattle to sheep: a view of the difficulties and success of commercial in vitro production of sheep embryos. Animal Reproduction, v. 9, p. 195-200, 2012.

SOUZA, J.M.G.; DUFFARD, N.; BERTOLDO, M.J.; LOCATELLI, Y.; CORBIN, E.; FATET, A.; FREITAS, V.J.F.; MERMILLOD, P. Influence of heparin or the presence of cumulus cells during fertilization on the in vitro production of goat embryos. Animal Reproduction Science, v. 138, p. 82-89, 2013.

SOUZA-FABJAN, J.M.G.; PANNEAU, B.; DUFFARD, N.; LOCATELLI, Y.; FIGUEIREDO, J.R.; FREITAS, V.J.F.; MERMILLOD, P. In vitro production of small ruminant embryos: Late improvements and further research. Theriogenology, Accepted for publication. 2014
SOUZA-FABJAN, J.M.G.;PEREIRA, A.F.; MELO, C.H.S.; SANCHEZ, D.J.D.; OBA, E.; MERMILLOD, P.; MELO, L.M.; TEIXEIRA, D.I.A.; FREITAS, V.J.F. Assessment of the reproductive parameters, laparoscopic oocyte recovery and the first embryos produced in vitro from endangered Canindé goats (Capra hircus). Reproductive Biology, v. 13, p. 325-332, 2013.

TAKUMA, T.; SAKAI, S.; EZOE, D.; ICHIMARU, H.; JINNOUCHI, T.; KAEDEI, Y.; NAGAI, T.; OTOI, T. Effects of season and reproductive phase on the quality, quantity and developmental competence of oocytes aspirated from Japanese black cows. Journal of Reproduction and Development, v. 56, p. 55-59, 2010.

TAN, W.L.; WAN KHADIJAH, W.E.; ABDULLAH, R.B. Effect of sperm insemination duration on in vitro fertilisation (IVF) performance on goats. Malaysian Journal of Science, v. 30, p. 105111, 2011.

TEIXEIRA, P.P.M.; PADILHA, L.C.; OLIVEIRA, M.E.F.; MOTHEO, T.F.; SILVA, A.S.L.; BARROS, F.F.P.C.; COUTINHO, L.N.; FLORES, F.N.; LOPES, M.C.S.; BANDARRA, M.B.; SILVA, M.A.M.; VASCONCELOS, R.O.; RODRIGUES, L.F.S.; VICENTE, W.R.R. Laparoscopic ovum collection in sheep: Gross and microscopic evaluation of the ovary and influence on oocyte. Animal Reproduction Science, v. 127, p. 169-175, 2011.

TERVIT, H.R. Laparoscopy/laparotomy oocyte recovery and juvenile breeding. Animal Reproduction Science, v. 42, p. 227-238, 1996.

VAZQUEZ, M.I.; FORCADA, F.; CASAO, A.; ABECIA, J.A.; SOSA, C.; PALACIN, I. Undernutrition and exogenous melatonin can affect the in vitro developmental competence of ovine oocytes on a seasonal basis. Reproduction in Domestic Animals, v. 45, p. 677684, 2010.

VIANA, J.H.; DE ALMEIDA CAMARGO, L.S.; DE MORAES FERREIRA, A.; DE SA, W.F.; DE CARVALHO FERNANDES, C.A.; DE PINHO MARQUES JUNIOR; A. Short intervals between ultrasonographically guided follicle aspiration improve oocyte quality but do not prevent establishment of dominant follicles in the Gir breed (Bos indicus) of cattle. Animal Reproduction Science,v. 84, p. 1-12, 2004.

WANI, N.A.; WANI, G.M.; KHAN, M.Z.; SIDIQI, M.A. Effect of different factors on the recovery rate of oocytes for in vitro maturation and in vitro fertilization procedures in sheep. Small Ruminant Research, v. 34, p. 71-76, 1999.

YOUNIS, A.I.; ZUELKE, K.A.; HARPER, K.M.; OLIVEIRA, M.A.; BRACKETT, B.G. In vitro fertilization of goat oocytes. Biology of Reproduction, v. 44, p. 1177-1182, 1991. 